\title{
Vive la différence? Women and trade unions in
}

\section{Britain}

Vive la différence? Femmes et syndicalisme en Grande-Bretagne

Sue Ledwith

\section{OpenEdition}

1 Journals

Electronic version

URL: http://journals.openedition.org/rfcb/1141

DOI: $10.4000 /$ rfcb. 1141

ISSN: 2429-4373

\section{Publisher}

CRECIB - Centre de recherche et d'études en civilisation britannique

\section{Printed version}

Date of publication: 27 July 2009

Number of pages: $87-112$

ISBN: 978-2-9115-8028-4

ISSN: 0248-9015

\section{Electronic reference}

Sue Ledwith, "Vive la différence? Women and trade unions in Britain », Revue Française de Civilisation Britannique [Online], XV-2 | 2009, Online since 01 November 2016, connection on 30 April 2019. URL : http://journals.openedition.org/rfcb/1141 ; DOI : 10.4000/rfcb.1141

\section{(c) $\oplus \Theta \Theta$}

Revue française de civilisation britannique est mis à disposition selon les termes de la licence Creative Commons Attribution - Pas d'Utilisation Commerciale - Pas de Modification 4.0 International. 


\title{
Vive la différence? Women and trade unions in Britain
}

\author{
Sue LEDWITH \\ Ruskin College, Oxford
}

In all respects, and especially in the field being discussed in this issue on British trade unions, women are both the same as (or similar to), and different from men. In a class analysis working women and men are each oppressed by capital in its various forms, with the expectation that they will both collectivise against this oppression. However in a patriarchal analysis women are also oppressed by men wherever they sit in the class structure. This fundamental difference leads in interesting directions, and informs the discussion in this article about women and gender politics in British trade unions.

Sameness expects class solidarity among men and women - but on men's terms. These include solidarity in adversity, militancy, commitment to trade unionism and political action in its support. Such expectations cannot be met by most women solely on men's terms. This has led to particular types of women's solidarity, as well as women being characterised by mainstream unionism as being passive workers, reluctant to take industrial action and lacking commitment to unionism and work because their primary commitment is to family.

However, while the proportion of women in British trade unions has now overtaken that of men, ${ }^{1}$ this does not mean that women have been absent or silent or passive in their trade unionism in the past, nor that they continue to be so. Rather it has meant that in traditional and official accounts of trade union history, women have been ignored or excluded. It has taken women trade unionists to actively challenge their traditional unions, and women researchers, scholars and supporters to write them back in. And only now in the twenty first century are 'mainstream' writers, academics and union leaders, overwhelmingly male, reading this literature, acknowledging the significance for organised labour of women and for the union movement, and starting to engage with those who are being increasingly embraced as the 'saviours' of labour movements worldwide.

In this article I aim to explore these tensions and paradoxes and the bases for them, discuss how exclusionary practices against women in the workplace and in trade unions have shaped their trade unionism over the 200 years since

\footnotetext{
${ }^{1}$ For the sixth consecutive year, in 2007, a higher proportion of women than men were trade union members (Mercer \& Notley, 2008). These are figures for all certificated UK unions. Not all are affiliated to the Trades Union Congress (TUC). However the discussion in this paper, and indeed, in most writing in the field, except where specified, refers to the TUC unions.
} 
industrialisation in Britain, and review women's strategies. In particular, women's rootedness and activism in their communities, families, work, and unions, have been marked by a willingness to work across groupings, and across identities of class, race/ethnicity, sexuality, disability, and so on, that is less evident among their brothers. A hallmark of women's activism is the carrying of their experiences and skills from one to the other, evolving and adapting approaches and methods as necessary in concert with both their own life cycle and prevailing external conditions. In writing about women in the British union movement, a large canvas, necessarily I have to be selective, so I have organised my discussion around some broad key themes, which themselves overlay social processes of exclusion, demarcation and segregation through to inclusion and transformation, tracing the thread of women being now outsiders, now insiders, now both. I draw on a range of published material both academic and trade union, my own observations of women's trade unionism over three decades, ${ }^{2}$ my work on two major research programmes in the 1980s and 1990s, and a current project on trade union leadership, and on running academic and other programmes for both women and men trade unionists.

\section{Her-story, as well as his-story}

It has taken feminist historians to reclaim women's history in the labour movement, as elsewhere. As Mary Davis puts it: 'redressing the balance in relation to women is not simply a matter of disproving the myths by discovering hitherto forgotten women leaders' ${ }^{3}$ It is about exhibiting the evidence that indicates that women were present and active, and also how they dealt with often apparently insuperable obstacles centred on male attitudes and practices. 'Her-story' illustrates the range and breadth of women's organising across and between their political and union interests over the last two centuries.

Early on in the 19th century industrial revolution, women were in the vanguard as workers, together with children, especially in the textile industry. Factory inspectors' returns and other sources show that from 1835 women outnumbered men - records show that out of a population of about $16 \mathrm{~m}$ in 1841 (census) women made up over half of the half a million workers in textiles, which was second only to agriculture as an employer of labour. ${ }^{4}$ Women were also early to organise collectively. The Manchester Spinners' Society, formed in 1795, was predominantly female. Textile workers' unions were forerunners to the New Unionism of mass organisation in the late 19th century. ${ }^{5}$ They were also the most progressive, becoming

\footnotetext{
${ }^{2}$ From 1979 until the early 1990s, I edited the women's pages of the journal of the print union SOGAT '82 (Society of Graphic and Allied Trades); for most of that time the general secretary was a woman: Brenda Dean, which undoubtedly had a strong impact on the union. Currently I am a lay officer of my own union, the University and College Union.

${ }^{3}$ M. DAVIS, Comrade or Brother? The history of the British Labour Movement 1780-1951. London: Pluto Press, 1993, p. 4.

${ }^{4}$ Ibid., p. 19.

${ }^{5}$ Old unionism, and apprentice based craft unionism, male, relied on skill and scarcity value of labour, with the engineering workers being in the vanguard of exclusion in these Closed unions. New unionism relied on sheer force of numbers, male and female. These Open unions welcomed women from the start, accounting for the first recorded real increase in women's TU
} 
the pioneers of mixed unions. Of supreme importance in terms of gender and class solidarity, they negotiated pay based on the rate for the job and not on the rate for the sex of the worker doing the job. ${ }^{6}$ This solidarity and the fact that the unions organised so widely in the cotton industry, enabled them to achieve through collective bargaining, fixed wage rates, something far in advance of other unions. The downside for women was the occupational segregation which saw men 'corner' the best paid skilled jobs and women doing the un and semi-skilled work. In addition, as Sarah Boston points out, the working conditions for women were appalling with women's exploitation second only to those of children. Outside the textile unions 'male trade unionists almost entirely washed their hands of the plight of women workers'.?

Unsurprisingly then, it was also in textile country that early demands were being made for political and economic reform. The demand by radical suffragists for 'womanhood suffrage' - the vote without a property qualification for all women over 21, 'electrified and mobilised' women in the Lancashire cotton towns and beyond. ${ }^{8}$ And in the 1820 s and 1830 s women played an active role campaigning for sexual equality and publicly promoting socialism as the only means for its achievement. Davis asserts that this period of industrialisation was 'unique in the extent to which male leaders of the labour movement were open and supportive of such initiatives'. ${ }^{9}$ For example, the Pioneer, the newspaper of the Grand National Consolidated TU (GNCTU) had a regular women's page and editorials written by the male editor and his wife Frances Morrison demanding equal pay for work of equal value. ${ }^{10}$ Nearly a hundred years later, when female suffrage was much closer to realisation, none of the labour or socialist organisations made the enfranchisement of women, or women's rights generally, a campaigning priority. ${ }^{11}$ And, as the mores of Victorian society strengthened, so did the paradigm of women's secondary role and her position in the family, and the concept of the male breadwinner, together with subsequent complexities and contradictions ${ }^{12}$ - all strait-jackets which women are still trying to shake off. Gender roles and segregation of work followed these contours - domestic service was the biggest single employer of female labour for example, and remained so until the Second World War a century later. Dressmaking, millinery and the like were all carried out in workshops or as home-working occupations. Few women worked against this grain, the exceptions such as women chain makers and 'pit brow lassies' in coal mines at the surface, attracting more attention because they were atypical. ${ }^{13}$

membership from around 50,000 in 1888 to about 432,000 in 1913 (DAVIS, Comrade or Brother ... op. cit., p. 95).

${ }^{6}$ S. BOSTON, Women Workers and Trade Unions. London: Lawrence \& Wishart, 1987, p. 23.

${ }^{7}$ Ibid. p. 24.

${ }^{8}$ M. DAVIS, Comrade or Brother ... op. cit., p. 113.

${ }^{9}$ Ibid. p. 38

${ }^{10}$ Idem.

${ }^{11}$ Ibid. p. 111.

${ }^{12}$ For further debate and detail see histories such as S. BOSTON, Women Workers ... op . cit., M. DAVIS, Comrade or Brother ... op. cit.; B. DRAKE (1920) Women in Trade Unions. London. Labour Research Department. Republished by Virago Press, 1984 and S. ROWBOTHAM, Hidden from History. London: Pluto Press, 1977 ( $3^{\text {rd }}$ edition).

${ }^{13}$ There is an annual celebration at the Black Country Living Museum of the women chainmakers' who in 1910 went on strike for 10 weeks for their right to a minimum wage for 
Over the decades women's increasing union membership has tended to reflect their increasing participation in the workforce, and also the fluctuations during periods of unemployment. For example between 1964 and 1970 women accounted for $70 \%$ of the increase in members of TUC unions, making up a third of union members. ${ }^{14}$ The highpoint of trade union membership density in the UK was 1979. Since then the overall decline in union membership has been fairly steady, although women's membership has held up better than men's. In 2007 density among women was $29.6 \%$ with men's density at $26.4 \%$ in 2007 . For women this was $0.2 \%$ points below the level it was in $1995(29.7 \%)$ while men's density was down $8.6 \%$ points since 1995 . Much of women's unionisation is in the public sector, where density is much higher than in the private sector - $59 \%$ in 2007 , women's density being $57.8 \%$, compared with $61.3 \%$ among men, ${ }^{15}$ and only $18 \%$ overall union density of the private sector. ${ }^{16}$

Women's union density is also now higher for women in managerial, professional and technical work, especially in non-affiliated (to the TUC) organisations. As might be expected, women consistently have lower representation in the more industrial occupations, and the highest union density for women is in education at 53.9\%. Among both men and women union density is highest among the over 50s, lowest in the 16-24 age group, and higher among full time workers than part timers across all age groups. Density was highest of all among black British workers at $29.4 \%$ in 2007 , with density at $28.3 \%$ for white workers and 23.2\% for Asian British workers. ${ }^{17}$

\section{Why women join unions, and become active}

Studies have found that commitment of members to their union is linked especially to socialisation factors relating to trade unionism, perceived benefits from the union, and to gender ${ }^{18}$ Reasons for women being favourable towards unions and their propensity to join tend to stem from broadly two directions: experience at the workplace and personal background and beliefs. Protection and support should they have problems at work, especially in relation to injustice to women, are commonly cited as triggers to activism ${ }^{19}$. Union family backgrounds and their union involvement is also important in women's initial propensity to activism. For

their industrial sector. Their dispute was an important step towards establishing a National Minimum Wage - finally achieved in 1999 (www.indymedia.org.uk Nov 2008).

${ }^{14}$ D. SINCLAIR, 'The Importance of Gender for Participation in and Attitudes to Trade Unionism', Industrial Relations Journal, v. 27, n. 3, 1196, p. 241.

${ }^{15}$ S. MERCER \& R. NOTLEY, Trade Union Membership 2007. A National Statistics Publication. London: Department for Business and Regulatory Reform, 2008, pp. 4-7.

${ }^{16}$ TUC, $A$ woman's place is in a union. Report to $75^{\text {th }}$ TUC Women's Conference March. London: TUC, 2005, p. 11.

${ }^{17}$ S. MERCER \& R. NOTLEY, Trade Union Membership 2007 ... op. cit. p. 8

${ }^{18}$ D. SINCLAIR, op. cit., p. 239.

${ }^{19}$ Sue LEDWITH, S, HAYES, M, JOYCE, P. and GULATI, A. 'The making of women trade union leaders', Industrial Relations Journal 21, 2, 1990; G. KIRTON \& G. HEALY, 'Transforming union women: the role of women trade union officials in union renewal' Industrial Relations Journal, 30: 31-34, 1999, p. 38; S. WALTERS, 'Female Part-time Workers' Attitudes to Trade Unions in Britain', British Journal of Industrial Relations. 40: 1 March 2002, pp. 49-68. 
example women became active in their print unions because 'we got our father's politics rammed down our throats, so I was always politically aware. I've done exactly the same and my family are all very political people', and at work 'because I could see where things were so wrong for the women'.

Women had also become politicised as feminists in the Women's Movement, or at university in student politics. ${ }^{20}$ Conversely, Walters found that hostile attitudes towards trade unions among part time women workers stemmed from their husbands' and/or other family members' negative experiences or attitudes towards trade unionism. ${ }^{21}$ She also found that women's part time/full time employment status may have little or no effect on their attitudes towards unions. Yet the high proportion of women working part time in the UK is important. For years the old closed male dominated craft and allied unions excluded part time workers on the grounds that they were low paid, thus undermining the 'rate for the (full time) job'. Given that being a union member gives leverage on higher pay than non unionists in the UK around $15 \%$ higher $^{22}$ - exclusion of part time women from their unions seriously undermines solidarity. By the $21^{\text {st }}$ century, unions have become acutely aware of this, and organising strategies increasingly are targeted at such groups. The importance of women's active participation was confirmed by Heery and Kelly's research in the 1980s when they found evidence that women officers were more committed to the recruitment of women into unions and to developing activism among the existing female membership. ${ }^{23}$

In their 1990s studies of people joining, staying and leaving their unions, Waddington, Whitston and Kerr found that although both men and women joined primarily for collective rather than individual reasons, women emphasised more highly than men that support for a problem at work was the most important reason for joining. Women especially sought mutual support, although they were slightly less likely than men to cite improved pay and conditions. ${ }^{24}$ However women were less likely to have been approached to join a union; most often they had had to make contact themselves. ${ }^{25}$ This is not altogether surprising, given that the majority of shop stewards (usually the first point of contact) are men, and as the slogan of the union Organising model attests, 'like recruits like'. Walters also found a major reason for women not joining was that they had not been asked. ${ }^{26}$ and Waddington and Kerr's research with UNISON found a markedly lower level of satisfaction among women

${ }^{20}$ S. LEDWITH et al 'The making of woman trade union leaders ...', op. cit., pp. 116-118, S. LEDWITH, 'The future as Female?' in C. PHELAN (ed) The Future of Organised Labour, Oxford: Peter Lang, 2006.

${ }^{21}$ S. WALTERS, 'Female part-time workers' attitudes ...' op. cit., p. 62.

${ }^{22}$ TUC, $A$ Woman's Place is in a Union. Report to $75^{\text {th }}$ TUC Women's Conference March. London: TUC, 2005, p. 7.

${ }^{23}$ E. HEERY \& J. KELLY 'Do female representatives make a difference? Women full-time officials and trade union work', Work, Employment and Society. Vol 2:4 pp. 487-505. December, 1988, p. 501.

${ }^{24}$ J. WADDINGTON and C. WHITSTON, 'Why Do People Join Unions in a Period of Membership Decline?' British Journal of Industrial Relations, Volume 35 Issue 4, pp. 515546, 1997, p. 524-5.

${ }^{25}$ Ibid. p. 534.

${ }^{26}$ S. WALTERS, 'Female part-time workers' attitudes ...' op. cit., p. 64. 
in relation to their contact with branch officers, stewards and full time officers. ${ }^{27}$

In our studies of UK printing unions, and of women in UNISON, women activists also faced hostility, harassment, sexism, and competition from men: there is a strong feeling a lot of the men would prefer a male deputy $\mathrm{FOC}^{28}$ to me.... It comes through pretty strong'. ${ }^{29}$ Nevertheless some supportive male mentors, usually officers senior to the women, were significant in encouraging women to take on leadership roles, although women recruiting, bringing on, sponsoring other women remain a key influence. ${ }^{30}$

Women's roles in the home and family are, as they always have been, important in determining women's union participation. In studies in the 1980s and 1990s we found that women with young children were less likely to attend meetings and be active in their unions. Once their children reached 11, the age at which secondary education normally begins in the UK, part time women return to work longer hours, and women generally were able to take more of an active part in their union. For example, $43 \%$ of women activists in our study of the GPMU (Graphical, Paper and Media Union) and UNISON had adult children, whereas only a quarter of those with children aged below 10 were active. ${ }^{31}$ Similarly, Kirton and Healy found that the active women in their study were 'atypical' of women in having no children, or grown-up children, being aged over 40 and in supervisory, management or professional full time jobs. In these characteristics, they related more to the traditional male activist model. ${ }^{32}$ The lack of affordable, quality childcare, expectations of women's role in the family, combined with union tendencies to hold meetings in the early evening, or Sunday lunchtimes - in the pub, combine to make it difficult for mothers of young children to take part fully in their unions. As the historians Jill Liddington and Jill Norris put it, union and political women have always had 'one hand tied behind us'. 33

As already discussed, a central tenet of the historical, and contemporary traditional valorisation of men and their work is their role as breadwinner, from which flow further principles. These include the family wage, men's primary attachment/commitment to work, their primacy at the workplace and in the home. In both sites the gender relations of reproduction and production have implications for women. When they reach the workplace women cannot undercut the breadwinner wage by claiming parity with men, besides they are already partly paid for through their men's family wage payment. Women with children are seen as unreliable workers since the family is prescribed as a mother's first responsibility, even though

\footnotetext{
${ }^{27}$ J. WADDINGTON, J. \& A. KERR, p. 160.

${ }^{28}$ FOC is Father of the Chapel (shop steward] in the print industry. Women are known as MOC; Mother of the Chapel.

${ }^{29}$ S. LEDWITH et al 'The making of woman trade union leaders ...', op. cit.,, p. 119.

${ }^{30}$ Ibid; F. COLGAN \& S. LEDWITH, 'Sisters Organising - Women and their Trade Unions' in S. LEDWITH \& F. COLGAN (eds). Women in Organisations: Challenging Gender Politics. Basingstoke: Macmillan Business, 1996.

${ }^{31}$ F. COLGAN \& S. LEDWITH, 'Sisters Organising ...', op. cit., p. 175.

${ }^{32}$ G. KIRTON \& G. HEALY, op. cit., p. 38.

${ }^{33}$ J. LIDDINGTON \& J. NORRIS, One Hand Tied Behind Us: The rise of the women's suffrage movement, Virago Press, 1978; new 21st anniversary edn., Rivers Oram Press, 2000.
} 
women in 19th century factories regularly gave birth under their machines so as not to jeopardise their position. Only during the second world war were nurseries liberally provided for women war workers, and those were quickly closed when the peace came. In twenty first century Britain childcare remains far from universal and affordable and women continue to make up the vast majority of part time workers, often working flexibly in precarious, multiple, jobs. Despite protective and equality legislation, these dilemmas are still exploited by employers who treat women as a 'reserve army of labour', taking them on at cheaper rates than men, and as a century ago, setting women and men workers against one another. From the early days of the industrial revolution male trade unionists sought to exclude women as competition and when women did accept low pay, as they must, with very few exceptions, they were castigated for lack of solidarity.

By accepting unquestioningly the dominant ideology of women as second class citizens and in labelling women as the problem, the men, with very few exceptions, failed to see how this divide and rule created a trap for themselves. ${ }^{34}$ Instead, the attitude which dominated the policies of the early trade union movement was that expressed by general secretary Henry Broadhurst to the TUC in 1875, who maintained that the main aim of a trade union with regard to women was to: 'bring about a condition... where their wives and daughters would be in their proper sphere at home, instead of being dragged into competition for livelihood against the great and strong men of the world' ${ }^{35}$

\section{Women organising}

In the face of implacable male opposition as illustrated by Broadhurst, above, attempts to organise women tended to come from outside the labour movement, often through the work of philanthropic middle class women. The most notable was the formation in 1874 under the leadership of Emma Paterson, of what became the Women's Trade Union League. ${ }^{36}$ The League fostered the growth of separate associations of women working in trades such as dressmaking, millinery and upholstering - 30 of these were formed between 1874-1886, although they were weak and shortlived. The strength of the League lay in its wide and financially strong base - partly a result of a deal that trade unions which admitted women would affiliate for a small fee, and in return the League would supply speakers and organisers around the country. By the 1890 s around 60 unions were affiliated, including 30 local associations of cotton operatives. ${ }^{37}$ In addition, the League got the first two women delegates elected to the TUC in $1875 .^{38}$ At that Congress a motion was carried unanimously: 'That the members regard with much satisfaction the development of the self relying trades union movement among women... and pledge themselves to assist in promoting it in their various localities' ${ }^{39}$ Later, the League became more militant seeing strikes as the main means of unionising women

\footnotetext{
${ }^{34}$ S. BOSTON, Women Workers ... op. cit. p. 16.

${ }^{35}$ Idem, M. DAVIS, Comrade or Brother ... op. cit. p. 84.

${ }^{36}$ M. DAVIS, op. cit. p. 84.

${ }^{37}$ S. BOSTON, Women Workers ... op. cit. p. 35.

${ }^{38}$ Ibid, p. 128, M. DAVIS, Comrade or Brother ... op. cit. p. 85.

${ }^{39}$ S. BOSTON, Women Workers ... op. cit. p. 34.
} 
workers, and campaigned for the extension of protective legislation. Inspired by the success of the women match workers' strike at the Bryant and May factory in 1888, and the involvement of socialist 'outsiders' like Annie Besant, other semi skilled workers organised and took militant action. ${ }^{40}$

This was a period of blossoming of women's organising. The Cooperative Women's Guild was set up in 1883, and by 1931 had 67,000 members in 1,400 branches. The National Federation of Women Workers (NFWW) led by Mary Macarthur probably did most to unionise women, especially during the mass strike wave of 1910-14.

The First World War (1914-8) also provided opportunities for women who went to work to fill the roles of those men who went to war. These moves were not left uncontested by their brothers however. 'Dilutees' or substitution workers as they were known were strongly resisted in spite of government directives and agreements with employers. In the print trades for example, retired and unemployed men members were brought back in, and the London Society of Compositors encouraged members to do overtime in second offices - known as 'smooting'. Only eight women became members, despite the union losing around 3,000 members to the fighting services. ${ }^{41}$

Nevertheless, the first world war was described by Drake as 'the first time in history, (that) women outside the cotton industry were learning the power of trade unionism'. The 'impulse to organise' was strongest among the 'substituted' women, who recognised that their wage rates were fixed by their union. This 'aroused' many women in other trades, especially for example, drapery, to take an interest in their unions for the first time ${ }^{42}$ with the National Union of Shop Assistants electing a woman president. Drake refers to the 'women's sphere' in unions being definitely enlarged but their duties being confined mostly to branch or districts and no women on the national executive of a single important general labour union. Of the 28 women delegates (out of 8-900 in total) to the 1918 TUC Congress, eight (29\%) were from the National Federation of Women Workers. ${ }^{43}$

In the four years of the war the female membership of all unions rose from less than 400,000 to well over $1,000,000$ (17\% of members) with the biggest growth in the general labour unions. The exclusive male unions, while still refusing to admit women, formed alliances with The National Federation of Women Workers, whose membership rose to about 80,000 . However Drake reports that on the whole, skilled women mechanics 'threw in their lot with other women, and joined general labour unions'. ${ }^{44}$

Being well aware of these issues and anticipating a postwar backlash, women's organisations joined forces to demand rights, some of which are still being sought a

${ }^{40}$ M. DAVIS, Comrade or Brother ... op. cit. p. 99.

${ }^{41}$ C. COCKBURN, Brothers: Male Dominance and Technological Change. London: Pluto, 1983, p. 36.

${ }^{42}$ B. DRAKE, Women in Trade Unions. London: Labour Research Department. Republished by Virago Press, 1984, p. 97.

${ }^{43}$ Ibid. p. 99.

${ }^{44}$ Ibid. p. 97. 
century later:

- $\quad$ Equal pay for equal work

- $\quad$ Regulation of wages in low paid trades

- $\quad 48$ hour week

- Abolition of fines

- More women factory inspectors

- $\quad$ Protection in the dangerous trades

- Maternity provision

- $\quad$ Co-operative homes for working girls

- Reforms in technical education

- The vote

This was followed up in the 1918 report of the Joint Committee of Industrial Women's Organisations where women called on all unions to be open to women workers $^{45}$. At the same time however, the women were aware of the danger of being swamped by more confident male unionists. They demanded special provision should be made in the rules for the representation of women on the governing bodies of the unions, and there should be inside each Trade Union special machinery for dealing with the organisation of women in the trade and with their special needs and grievances'. Their proposals included a Women's Council, or sub committee of the Executive and the appointment of women organisers and officials, stressing the importance of women organising in encouraging women to take 'a large part in the management of their own affairs'. The women wanted their 'autonomy' to be safeguarded, pointing out that it was idle to deny that there are industrial problems which affect women specially and which require special treatment'. ${ }^{46}$

Meanwhile, as earlier in union history, the new mass membership unions adopted a rather different position, especially the transport unions which insisted women working on the railways or buses during the first war must become members. In January 1918, the victorious strike for equal pay by women bus conductors who were to be given only a fifth of the men's award, was supported by the men. Barbara Drake pointed out how women leaders, such as Mary Macarthur were quick to exploit the strike and get press coverage in the ongoing campaign for the principle of women's equal pay. ${ }^{47}$

The unmet demands remain on women's trade union agendas today, and have been raised time and again through the 20th century. Each time the arguments have to be made over again. Between the two world wars came the slump of the 1930s, itself following a long period of defensive strikes, culminating in the General Strike of 1926 in which the working class was forced into retreat. It was estimated that out of $5,750,000$ women at work only about a sixth were in unions. In large part this was due once again to the exclusionary attitudes and practices of male trade unionists, with women working in jobs which were 'hard to organise', especially for example the

\footnotetext{
${ }^{45}$ S. ROWBOTHAM, Hidden from History. London: Pluto Press, 1977 ( $3^{\text {rd }}$ edition), p. 117.

${ }^{46}$ Ibid. p. 118

${ }^{47}$ B. DRAKE, Women in Trade Unions. op. cit. pp. 92-93.
} 
hated domestic service which women were forced to re-enter when they could not find other work. During this period the women's trade unions were not able to defend their striking members, although they did play an important educational role. The tension between women's autonomy and their integration, and the danger of being controlled by men in either situation, was identified once again by Barbara Drake in her 1924 report Women in Trade Unions. Again, she advocated women's advisory councils in mainstream unions to help women members with their special problems, and encourage them to participate in their unions. Furthermore such women needed to be conscious of discrimination and to ensure continuous pressure from the rank and file. ${ }^{48}$

As the presence of women in the workforce was less hidden, female recruitment sought to stem declining union membership, and sexism in the labour movement became more marked. ${ }^{49}$ On the other hand what Boston refers to as 'one of the most significant gestures of recognition of women workers by the trade union movement' was made in 1942 when the engineers' union at last voted to accept women members. The new rules provided for a separate annual conference for women, and the right to vote in all elections. The first women's conference was held in 1943 and although the union president paid tribute to the burden of the three jobs which women carried - at home and at work and in the union, there was scepticism among women about the reality of such inclusionary gestures. ${ }^{50}$ Boston also comments on the presence of entrenched male attitudes in the president's speech about gender roles both at work and at home. ${ }^{51}$

Likewise, women's separate organising continues to raise strong attitudes for and against. As Linda Briskin ${ }^{52}$ has established, there is a strategic balance to be maintained between autonomy leading to exclusion or marginalisation, ghettoisation and powerlessness, and integration with its danger of take over and assimilation leading to powerlessness. Other researchers have shown how all of these can happen, and yet also how autonomous organising, working in for example, women's groups, Black women's groups, women's education and campaigning provides a critical space for the empowerment of women, and development of collective political strategies to carry into the mainstream in order to change structures and cultures. ${ }^{53}$ Ledwith and Colgan ${ }^{54}$ have also discussed the importance of women

${ }^{48}$ ROWBOTHAM, Hidden from History op. cit., p. 130.

${ }^{49}$ M. DAVIS Comrade or Brother ... op. cit., pp. 208-209.

${ }^{50}$ S. BOSTON, Women Workers ... op. cit., pp. 212-214.

${ }^{51}$ Ibid., p. 215.

52 L. BRISKIN, 'Union Women and Separate Organizing', in L. BRISKIN and P. MCDERMOTT (eds), Women Challenging Unions, Toronto: University of Toronto Press, 1993, pp. 89-108 and L. BRISKIN, ‘Autonomy, Diversity and Integration: Union Women's Separate Organizing in North America and Western Europe in the Context of Restructuring and Globalization', Women's Studies International Forum, 22, 4, 1999, 543-554.

${ }^{53}$ F. COLGAN \& S. LEDWITH, 'Sisters Organising', op. cit.; S. LEDWITH \& F. COLGAN, 'Tackling Gender, Diversity and Trade Union Democracy: A Worldwide Project?', in COLGAN F. \& LEDWITH S. (eds), Gender, Diversity and Trade Unions: International Perspectives, London: Routledge, 2002; J. PARKER, 'Women's Groups in British Unions', British Journal of Industrial Relations. 40, No. 1. 23-48, 2002; J. PARKER, Women's Groups and Equality in British Trade Unions, Lampeter: Edwin Mellen, 2003; G. KIRTON \& G. HEALY, 'Shaping union and gender identities: a case study of women-only trade union 
preparing for and 'seizing the moment' when change occurs and conditions are favourable, and Ledwith ${ }^{55}$ has commented on social processes which might be involved in the development of a women's counter-hegemony in pursuit of gender and diversity democracy in trade unions.

\section{Women's structures and women leaders}

These processes can be seen in the chronology of women's organising already discussed in the tracing of 'her' stories so far. In addition, the story of the UK TUC women's structures can be mapped through the debates at women's conferences, the TUC Women's Committee and through its increasingly confident and assertive role, and the continued development of the Equal Rights department. The TUC itself reached a watershed when in 2003 Frances O'Grady became the first woman deputy general secretary of the TUC, and her colleague Kay Carberry was appointed assistant general secretary. This compares interestingly with the previous 80 years; in 1920, for the first time, the TUC voted to form a general council (GC) with 17 industrial groupings. The NFWW demanded women's representation, and an $18^{\text {th }}$ group representing women, was established with two women's seats guaranteed and this Women Workers' Group also took on the role and work of the Women's TU League which had worked so effectively over the previous 47 years. ${ }^{56}$ The women's success was followed five years later by the setting up of an annual women's conference. Boston describes this position as an 'uneasy one between separatism and unity' as although they now had a separate and institutionalised platform the women's conference had no power to make policy ${ }^{57}$. Indeed until the 1980 s it was known in its various forms as the Women's Advisory Committee (my italics), and still today only one resolution passed at the Women's Conference can be selected to go forward to the main 'men's' annual Congress, with no guarantee of succeeding. As can be seen in Table 2 'advisory' committee remains the preferred nomenclature for several of the UK's biggest unions. Nevertheless the 1970s and 1980s were a time of early consolidation of women's structures and measures and an increase in women's profile and activities. ${ }^{58}$ The duration of the TUC Women's Conference increased, delegates became solely female whereas previously male delegates were accepted, the Committee was restructured to incorporate more democratic procedures such as rotating the chair. The term 'advisory' was dropped from its title and an Equal Rights department was set up within the TUC. Charters for women within their trade unions and for women at work were adopted, and additional women's seats, including for

courses', British Journal of Industrial Relations. 42: 2 June, 2004, pp. 303-323; S. LEDWITH, 'The future as Female?' in C. PHELAN (ed), The Future of Organised Labour, Oxford: Peter Lang, 2006.

${ }^{54}$ S. LEDWITH \& F. COLGAN, 'Tackling Gender, Diversity and Trade Union Democracy: A Worldwide Project?', in F. COLGAN \& S. LEDWITH (eds), Gender, Diversity and Trade Unions: International Perspectives, London: Routledge, 2002, p. 22.

${ }^{55} \mathrm{~S}$. LEDWITH, 'Encounters between gender and labour politics; towards an inclusive trade union democracy', Equality Theory and Research, ed. OZBILGIN M. and ELGAR E. 2009/forthcoming.

${ }^{56}$ S. BOSTON, Women Workers ... op. cit., p. 147.

${ }^{57}$ Ibid., p. 148 .

58 A. COOTE \& B. CAMPBELL, Sweet Freedom: the struggle for women's liberation. Oxford: Blackwell, 1987 ( $2^{\text {nd }}$ edition $)$, p. 159. 
black women, ensured a better representation of women on the General Council.

Throughout the 1970s there were also fierce arguments in the movement about whether or not special measures should be taken to increase and encourage women. Should there be special education programmes, committees, seats? The TUC Women's Advisory Committee (WAC) in 1977 expressed concern that some public sector unions had stopped sending delegates to the annual TUC Women's Conference on the grounds that it was isolated and sidetracked women's problems which should be dealt with at annual conference. If this trend continued it could mean that the conference and the committee could become increasingly unrepresentative of large sections of women with the Movement. ${ }^{59}$ Some whitecollar unions made vigorous efforts to disband the TUC women's conference on the grounds that it was a ghetto and an anachronism and should be discontinued, chiefly because 'the fact women can now claim equal rights with men' (and) the trade unions' opposition to discrimination and progress made towards fuller participation by women members in the general work and direction of the movement'. Against this motion it was argued that women would continue to need a special platform until they really were equal. This was carried and the conference was saved, ${ }^{60}$ and strengthened by the increase by five, to eight, and from 1981 to ten, of women elected by the women's conference to serve on the WAC, with an increase from two to five seats on the Women Workers Group of the main TUC General Council. ${ }^{61}$ Women also continued to campaign for the wider issues. The 1977 conference that year voted to support the General Council's campaign against racial discrimination, drawing attention to the position of many immigrant women, and vigorously opposed moves to amend the Abortion Act of $1967 . .^{62}$

This was also a period of economic crises though, when unions became preoccupied with saving members' jobs and defending existing wages. Once again, fighting against female disadvantage was not a top priority. Partly as a result of dropping membership and attempts to consolidate union power a substantial number of union mergers took place, further reducing the opportunities for women and other diversity groups to increase their representation in leadership positions and for women's employment as officers in unions. ${ }^{63}$ Having said that, a decade later a review of mergers of unions in which the aim was transformative, to change structures in pursuit of democracy and inclusiveness, has recently concluded that merger reforms can contribute to gender democracy. ${ }^{64}$

Women themselves were, and remain, ambivalent about separate structures and autonomous organising. Mary Macarthur, the founder of the NFWW had always seen separatism as a necessity of circumstance, not a feminist principle. ${ }^{65}$ Yet within

${ }^{59}$ TUC, Women Workers: Report of the $48^{\text {th }}$ annual conference of representatives of trade unions catering for women workers. London: TUC, 1977, p. 2.

${ }^{60}$ A. COOTE \& B. CAMPBELL op. cit., p. 169-70.

${ }^{61}$ TUC, Women Workers ..., op. cit., p. 2, TUC, $51^{\text {st }}$ TUC Women's Conference: Report for 1980-81 of the TUC Women's Advisory Committee. London: TUC, 1981, p. 4.

${ }^{62}$ TUC, Women Workers ..., op. cit., pp. $12 \& 18$.

${ }^{63}$ F. COLGAN \& S. LEDWITH, 'Sisters Organising', op. cit., pp. 158-9.

${ }^{64}$ A. MCBRIDE \& J. WADDINGTON, 'Union Mergers and Gender Democracy', Bulletin of Comparative Labour Relations, 67, Challenges of European Employment Relations, 2008.

${ }^{65}$ S. BOSTON, op. cit., p. 149. 
ten years of the NFWW electing to merge, in 1920, with the National Union of General Workers (NUGW), this 'most militant union in the history of women's organisations, which had existed for a mere fourteen years and organised more strikes than most unions do in a long history, became 'submerged'.' It had been so effectively silenced that the merged union did not send one woman delegate to the 1930 TUC conference. ${ }^{66}$ By the $21^{\text {st }}$ century these structural issues had been addressed, as can be seen in Table 1 (see below). Women made up $45 \%$ of the membership of the NUGW, now the GMB, with women delegates to the annual Congress in 2007 also being $45 \% .^{67}$

Other women, then, and now, black women as well as white, have however seen autonomous organising as both necessary and essential: '...once I knew about the Black Members Group (in UNISON) it was different because at least there were people there that you could relate to and talk to...' (Black woman activist 1996). ${ }^{68}$ Indeed the public services union UNISON, formed in 1993 from the merger of three unions, put equality at the heart of its constitution, with the trinity of gender proportionality in the structures, fair representation in this across all groupings in the union, and the third most far seeing and most contentious strategy of selforganisation, all legitimatised in the Rule Book and promising 'adequate' funding and other resources. ${ }^{69}$ In this ground breaking approach, UNISON publicly acknowledged, and fiercely contested, the need for recognition, representation and resources needed by 'oppressed groups' if the new union was going to make a real attempt at a new pluralist form and character of inclusivity and democracy. ${ }^{70}$

Increasingly over the decades, women have been demanding both a voice in the mainstream, and women's structures as a site to develop voice, visibility and strategies. Table 2 (see below) shows the situation in 2007-8 in twelve of the largest TUC unions, and it can be seen that women's structures, especially when these are consistent across the four main areas of reserved seats, a national committee and conference and a national officer for women, do deliver a better proportional representation in terms of 'the numbers', than those which do not. Nevertheless of those twelve, only in two, Prospect and the UCU, are women represented in proportion to their membership, or slightly better, and in both unions women are in a minority in terms of membership. Even UNISON, for all its promise to achieve gender proportionality in its elected structures by the year 2000, has never done better than ensure women are two-thirds of the national executive rather than the $75 \%$ they should be. Indeed as Jane Parker points out, the tendency is that the unions with the highest proportion of women members on the whole tend to develop fewer

${ }^{66}$ Ibid., p. 150.

${ }^{67}$ SERTUC, Treading Water.... SERTUC's Eighth Survey of Equality in Trade unions. London: Southern and Eastern Regional Council, 2008.

${ }^{68}$ COLGAN F. \& LEDWITH S. (eds), Gender, Diversity and Trade Unions: International Perspectives, London: Routledge, 2002, p. 178.

${ }^{69}$ UNISON Rules 1993, London: UNISON, 1993.

${ }^{70}$ B. FRYER, 'The making of UNISON: a framework to review key events, processes and issues' in M. TERRY (ed) Redefining Public Sector Unionism: UNISON and the future of trade unions. London: Routledge, 2000, p. 42. 
and a smaller range of women only initiatives ${ }^{71}$

Table 1. Women in the structures ${ }^{72}$ in 12 selected large UK trade unions affiliated to the TUC. 2007/2008.

\begin{tabular}{|l|l|l|l|l|l|l|}
\hline & ATL & CWU & GMB & NASUWT & NUT & PCS \\
\hline $\begin{array}{l}\text { Members. } \\
\% \text { women }\end{array}$ & $\begin{array}{l}161,806 \\
75 \%\end{array}$ & $\begin{array}{l}240,000 \\
20 \%\end{array}$ & $\begin{array}{l}600,066 \\
45 \%\end{array}$ & $\begin{array}{l}265,202 \\
68 \%\end{array}$ & $\begin{array}{l}270,000 \\
76 \%\end{array}$ & $\begin{array}{l}311,820 \\
60 \%\end{array}$ \\
\hline $\begin{array}{l}\text { Women as \% on } \\
\text { National Executive }\end{array}$ & $42 \%$ & $17 \%$ & $41 \%$ & $24 \%$ & $40 \%$ & $34 \%$ \\
\hline $\begin{array}{l}\text { Women as \% at own } \\
\text { national conference }\end{array}$ & $50 \%$ & $16 \%$ & $27 \%$ & $49 \%$ & $50 \%$ & $33 \%$ \\
\hline $\begin{array}{l}\text { Women as \% of } \\
\text { delegates to 2007 TUC } \\
\text { national conference * }\end{array}$ & $48 \%$ & $29 \%$ & $49 \%$ & $45 \%$ & $49 \%$ & $61 \%$ \\
\hline $\begin{array}{l}\text { Women as \% national } \\
\text { officers }\end{array}$ & $51 \%$ & $29 \%$ & $23 \%$ & $72 \%$ & $42 \%$ & $32 \%$ \\
\hline $\begin{array}{l}\text { Women as \% regional } \\
\text { officers * }\end{array}$ & $51 \%$ & $8 \%$ & na & $42 \%$ & $50 \%$ & $27 \%$ \\
\hline $\begin{array}{l}\text { Women as \% branch } \\
\text { officers + }\end{array}$ & $49 \%$ & $15 \%$ & na & $30 \%$ & na & $41 \%$ \\
\hline $\begin{array}{l}\text { Women as \% of } \\
\text { stewards/reps + }\end{array}$ & $76 \%$ & $15 \%$ & na & $59 \%$ & na & $52 \%$ \\
\hline
\end{tabular}

\begin{tabular}{|c|c|c|c|c|c|c|}
\hline & $\begin{array}{l}\text { PRO- } \\
\text { SPECT }\end{array}$ & UCU & UNISON & $\begin{array}{l}\text { UNITE } \\
\text { Amicus }\end{array}$ & $\begin{array}{l}\text { UNITE } \\
\text { T\&G }\end{array}$ & $\begin{array}{l}\text { USDA } \\
\mathrm{W}\end{array}$ \\
\hline $\begin{array}{l}\text { Members as } \\
\% \text { women }\end{array}$ & $\begin{array}{l}101,500 \\
21 \%\end{array}$ & $\begin{array}{l}116,310 \\
46 \% \\
50 \% 2004^{73}\end{array}$ & $\begin{array}{l}1,343,000 \\
76 \%\end{array}$ & $\begin{array}{l}1,100,000 \\
27 \% \\
16 \% 2004^{74}\end{array}$ & $\begin{array}{l}747,617 \\
26 \%\end{array}$ & $\begin{array}{l}353,985 \\
58 \%\end{array}$ \\
\hline $\begin{array}{l}\text { Women as \% on } \\
\text { National Executive }\end{array}$ & $23 \%$ & $49 \%$ & $64 \%$ & $\begin{array}{l}19 \% \\
{[2004]}\end{array}$ & $33 \%$ & $41 \%$ \\
\hline $\begin{array}{l}\text { Women as \% at own } \\
\text { national conference }\end{array}$ & $14 \%$ & $\begin{array}{l}39 \% \\
{[2004]}\end{array}$ & $60 \%$ & $31 \%$ & $19 \%$ & $51 \%$ \\
\hline $\begin{array}{l}\text { Women as \% of } \\
\text { delegates to } 2007 \text { TUC } \\
\text { national conference } *\end{array}$ & na & $\begin{array}{l}45 \% \\
{[2004]}\end{array}$ & $59 \%$ & $\begin{array}{l}26 \% \\
{[2005]}\end{array}$ & $\begin{array}{l}30 \% \\
{[2005]}\end{array}$ & $41 \%$ \\
\hline $\begin{array}{l}\text { Women \% national } \\
\text { officers }\end{array}$ & $41 \%$ & $\begin{array}{l}39 \% \\
{[2004]}\end{array}$ & $40 \%$ & $19 \%$ & $19 \%$ & $\begin{array}{l}37 \% \\
{[2004]}\end{array}$ \\
\hline $\begin{array}{l}\text { Women as \% regional } \\
\text { officers * }\end{array}$ & na & $41 \%$ & $43 \%$ & $23 \%$ & $17 \%$ & $27 \%$ \\
\hline $\begin{array}{l}\text { Women as \% branch } \\
\text { officers }+\end{array}$ & $21 \%$ & na & $49 \%$ & $27 \%$ & $12 \%$ & $44 \%$ \\
\hline $\begin{array}{l}\text { Women as \% of } \\
\text { stewards/reps + }\end{array}$ & $23 \%$ & na & $50 \%$ & $23 \%$ & $19 \%$ & $51 \%$ \\
\hline
\end{tabular}

Sources: Main source: SERTUC [2008], plus: * Labour Research (2008), +TUC (2008)

KEY: ATL Association of Teachers and Lecturers, CWU Communication Workers Union, GMB General Municipal and Boilermakers, NASUWT National Association of Schoolmasters Union of Women Teachers, NUT National Union of Teachers, PCS Public and Commercial Services Union, NATFHE National Association of Teachers in Further and Higher Education, UCU University and College Union, UNITE/Amicus Amicus and the Transport \& General

${ }^{71}$ J. PARKER, 'Women's Groups in British Unions', British Journal of Industrial Relations. 40, No. 1. 23-48, 2002.

${ }^{72}$ For more details, especially on structures for Black and Minority Ethnic members (BAME), Lesbian Gay, Bisexual and Transgender [LGBT] members, and Disabled members, see SERTUC reports, and individual union websites.

${ }^{73}$ Figures for NATHFE, one of the two partner unions in the UCU merger of 2007. (SERTUC 2004).

${ }^{74}$ Figures for AMICUS prior to the Unite merger. (SERTUC 2004). 
Workers Union merged into UNITE; at the time of writing it remains operating in two sections.

Table 2. Equality measures in UK trade unions 2007/8

\begin{tabular}{|c|c|c|c|c|c|c|c|c|c|c|c|c|}
\hline WOMEN & 当 & ל & $\sum_{0}^{\infty}$ & $\begin{array}{l}\bar{b} \\
\vdots \\
\bar{z} \\
z \\
z\end{array}$ & 芸 & $\bar{Q}$ & 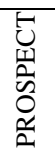 & ? & 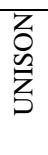 & 窎. & 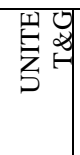 & $\begin{array}{l}3 \\
\vdots \\
5 \\
2\end{array}$ \\
\hline $\begin{array}{l}\text { Woman general } \\
\text { secretary }\end{array}$ & $\mathrm{Y}$ & $\mathrm{N}$ & $\mathrm{N}$ & $\mathrm{Y}$ & $\mathrm{Y}^{*}$ & $\mathrm{~N}$ & $\mathrm{~N}$ & $\mathrm{Y}$ & $\mathrm{N}$ & $\mathrm{N}$ & $\mathrm{N}$ & $\mathrm{N}$ \\
\hline $\begin{array}{l}\text { Reserved seats in } \\
\text { own structures }\end{array}$ & $\mathrm{N}$ & $\mathrm{N}$ & $\mathrm{Y}$ & $\mathrm{Y}$ & $\mathrm{N}$ & $\mathrm{N}$ & $\mathrm{N}$ & na & $\mathrm{Y}$ & $\mathrm{Y}$ & $\mathrm{Y}$ & $\mathrm{Y}$ \\
\hline $\begin{array}{l}\text { Reserved seats on } \\
\text { TUC Congress }\end{array}$ & na & na & $\mathrm{Y}$ & $\mathrm{Y}$ & na & na & na & na & $\mathrm{Y}$ & $\mathrm{Y}$ & $\mathrm{Y}$ & $\mathrm{Y}$ \\
\hline $\begin{array}{l}\text { National } \\
\text { Committee }\end{array}$ & $\mathrm{N}$ & 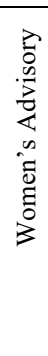 & 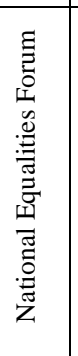 & 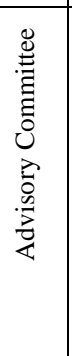 & 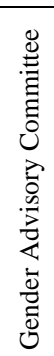 & 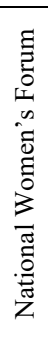 & $\mathrm{N}$ & & & & & 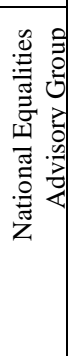 \\
\hline $\begin{array}{l}\text { National } \\
\text { Conference/ } \\
\text { event }\end{array}$ & $\mathrm{N}$ & $\mathrm{Y}$ & $\mathrm{Y}$ & $\mathrm{Y}$ & $\mathrm{N}$ & $\mathrm{Y}$ & $\mathrm{N}$ & & & & & 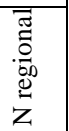 \\
\hline National officer & 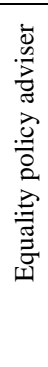 & 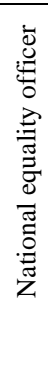 & 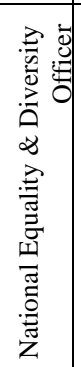 & 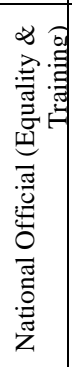 & 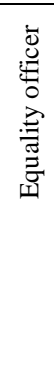 & 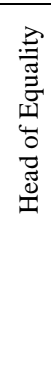 & 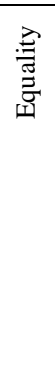 & 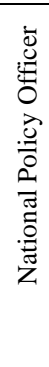 & 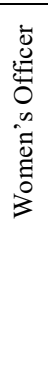 & 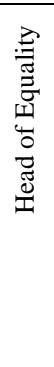 & $\lambda$ & 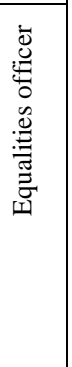 \\
\hline
\end{tabular}

Sources: SERTUC [2008], TUC (2008), Labour research (2008), * acting

This tendency continues. Introducing the most recent survey of equality in unions carried out by the South East Region TUC (SERTUC), Megan Dobney, Regional Secretary, commented that some of the unions still showed 'a dramatic 
under-representation of women at the decision-making levels of executive committees and conferences'. ${ }^{75}$ Of the unions responding to the survey, only UNISON had a national officer specifically for women. ${ }^{76}$ Twelve unions held an annual women's event or conference, nine had training and education programmes for women, ten publish journals for women. ${ }^{77}$ An area which has improved in recent years is the proportion of paid officers who are women, although there is some way to go to achieve proportionality. These, together with senior elected women leaders, are significant in providing visible role models, and support for one another in what is often a difficult or hostile environment. A typical response is the one from the woman who said: 'when I'm negotiating on behalf of all the members, men and women, I'm one of the boys. When I'm raising women's issues, I'm that damn woman' ${ }^{78}$

In 2003 the TUC began a biennial equality audit, which in 2007 covered $98 \%$ of all TUC-affiliated union members. ${ }^{79}$ The subsequent report found that women were worst represented at branch officer level, as can be seen in Table 1. Only in two unions were women represented at this local level in proportion to their membership, and they were male dominated unions - Prospect and Amicus. Women were also poorly represented on their national executives, with two-thirds not reaching proportionality with their female memberships. Only nine unions $(16 \%)$ had reserved seats on their national executive for women.$^{80}$ No wonder then, that there are so few women leading British trade unions. At the end of 2008 in the twelve largest unions, there were four; all in teaching unions, one being acting General Secretary (see Table 2), although none of these are anywhere near proportionality in their main elected structures, as shown in Table 1.

\section{From washing line to picket line - organising, militancy and subverting stereotypes}

As we have already seen, from the start women have always been more willing to organise collectively and inclusively across a range of organisations and have been effective in organising women in small workplaces and marginal work - areas which traditional masculinised unionism has long categorised as 'difficult to organise'. Women also have a tradition of organising in communities, including in strike situations where family poverty and debt led wives to pressure their men to return to work, as well as in their support. In the 1920s South Wales miners' wives tarred and feathered men who broke a strike. ${ }^{81}$ Such traditions continue in close occupational communities, being reprised half a century later during the 1984 mineworkers' dispute. The activities of the Women Against Pit Closures (WAPC)

75 SERTUC, Treading Water.... SERTUC's Eighth Survey of Equality in Trade Unions. London: Southern and Eastern Regional Council, 2008, p. 2.

${ }^{76}$ Ibid., p. 7.

${ }^{77}$ Idem.

${ }^{78}$ F. COLGAN \& S. LEDWITH, 'Sisters Organising ...', op. cit., p. 160.

${ }^{79}$ TUC Equality Audit. A Statistical Report on Trade Union Action on Equality, London: TUC, 2007, p. 2.

${ }^{80}$ Ibid., p. 4.

${ }^{81}$ ROWBOTHAM, Hidden from History, op. cit., p. 133. 
transformed not only the strike, but the relationship between the mining communities and the left, and the lives and politics of the women themselves ${ }^{82}$. Many also experienced a revolution in their domestic relations as their husbands were left to do the housework and childcare while the women ran the strike kitchens and attended meetings and rallies. Although these women did not think of themselves as feminists, this rejection was thought to signify a class rather than a gender identity; there was plenty of evidence that gender relations were contested during the strike as women asserted their right to a place in it (Shaw and Mundy 2005:152). In making links with other political groups such as black activists, lesbians and gay men, and Greenham ${ }^{83}$ women, they brought about 'an extraordinary cross-fertilization of left politics ${ }^{84}$ These examples were repeated among dock-workers wives in Liverpool in the 1996 fight against the return to casualisation of dock work. Like the women against pit closures, Women of the Waterfront (WOW) travelled far and wide, including to France, and to San Francisco, to speak and raise awareness. For these women, community, family and work are inextricably woven together:

I realized it wasn't just about the Liverpool dockers. This fight is a fight for workers everywhere, no matter what colour, what country, what language. It's all about the bosses putting the boot on the workers and destroying unions, family lives and just wanting to make money on the backs of workers, with casual labour and low pay. It didn't matter how long we'd been on the docks. This was a fight to stop the bosses destroying the lives of our families and taking the heritage of these men and their fathers and their sons for a hundred years. And we've mobilized and organized. It didn't take us long, because when you're fighting for survival, there's an instinct in a woman to fight to protect her family. ${ }^{85}$

As well as a potent form of organising, those other essential elements, the raising of women's consciousness, gains in confidence and new political skills kick in: 'we organized and went so far, further than any of us thought we'd go - we always say from the washing line to the picket line to the world platform '. ${ }^{86}$

In this sphere we can include ethnicity with the identifiers of community, family and class, through disputes involving another group of women deemed 'passive' - Asian workers. At the North London photo-processing Grunwick site in the 1970s, Mrs Jayaben Desai led a walkout over appalling working conditions, which developed into a demand for union recognition. Although the two-year dispute did not succeed in gaining recognition, the elevation of Asian women strikers into the public eye challenged the British public's prejudices of South Asian

${ }^{82}$ A. COOTE \& B. CAMPBELL, Sweet Freedom ... op. cit., p. 179.

${ }^{83}$ Women against nuclear weapons who camped and demonstrated and campaigned at the US airbase at Greenham Common in Berkshire.

${ }^{84}$ A. COOTE \& B. CAMPBELL, Sweet Freedom ... op. cit., p. 179.

${ }^{85}$ Dispatcher, 1997.

${ }^{86}$ Ibid. 
women as docile, submissive, difficult to unionise and as exploitable cheap labour ${ }^{87}$ and in 2007 Mrs Desai was given an award for the Asian woman of the Year on the 30th anniversary of the Grunwick strike. A more recent notable dispute involving Asian women was the 2005 walkout involving contract catering Gate Gourmet workers at London Airport. In these, and other significant cases, such as Imperial Typewriters in 1974 and the Chix bubble gum workers in $1979,{ }^{88}$ the women subverted stereotypes, emerging as leaders and supported by the community, although not always by the wider political and trade union movements.

Sivanandan observes that in strike after strike Asian workers have not only taken on the employers and sometimes won (limited) victories, but have also battled against racist trade unions which have either dragged their feet or quite often denied them the support they would have afforded white workers. Most blatant was in May 1974 when Asians at Imperial Typewriters went on strike over differentials between white and Asian workers. The unions refused their support and the strikers, supported by other black workers, had to fight both union and management (bolstered by the extreme right-wing party, the National Front). ${ }^{89}$

\section{The battle for Equal Pay}

Perhaps the most compelling indicator of women's success, or not, in gaining equity in the labour market and the level of support by their unions, is pay. As already discussed, equal pay has long been and continues to be a central concern of women trade unionists.

In 1888 Clementina Black of the Women's TU League moved the first successful equal pay resolution at the TUC. Presciently the resolution stated: 'it is desirable, in the interests of both men and women, that in trades where women do the same work as men, they shall receive equal payment ${ }^{90}$. But the battle to get the brothers to agree remains long and difficult, and also cuts across the classes. In the early 1900s the growing numbers of middle class women teachers' Equal Pay League campaigned for equal pay, but broke away from its parent National Union of Teachers over the issue ${ }^{91}$ and remained a separate union until 1976 when it merged with the men to form the National Association of Schoolmasters Union of Women Teachers (NASUWT) ${ }^{92}$.

In the early days, in the 19th century, despite the rhetoric, in practice little was done by the union movement to campaign for equal pay. Rather, the hope was that if

${ }^{87}$ J. DROMEY \& G. TAYLOR, Grunwick, the Workers' Story. London; Lawrence and Wishart, 1978, S. LAHIRI, 2002, p. 122, Moving Here. Migration Histories, www.movinghere.org.uk accessed 21/11/08.

${ }^{88}$ R. GUPTA, 'Heroines of the Picket'. London: The Guardian, 2005.

${ }^{89}$ SIVANANDAN A., 'The Grunwick Strike', Race \& Class, Vol. 19, no. 1, summer, 1977.

${ }^{90}$ S. BOSTON, Working Women ... op. cit. p. 57.

${ }^{91}$ Ibid., p. 81

92 Trade Union Family Trees, Teachers' Trade Unions. Trade Union Ancestors, www.unionancestors.co.uk accessed Nov 23, 2008. 
implemented women would price themselves out of the labour market ${ }^{93}$. For decades the TUC remained lukewarm, on the one hand urging the government to implement Equal Pay in the public sector while accepting it as a lost cause in the private exemplified in the difficult period post world war two by the view that in the light of ...the continuing need for counter-inflationary policies,... decided that a further approach by the TUC to the government on equal pay would be inappropriate at the present time'. ${ }^{94}$ During this time, unions in industries with a high proportion of women, such as the teachers, local government workers, shop workers, and post office workers were not only calling for a strict application of the marriage bar, but refused to campaign for or demand equal pay, instead pursuing claims maintaining pay differentials between men and women..$^{95}$ At the 1949 TUC Congress, conference ditched the issue altogether. ${ }^{96}$ Earnings remained, on average, $50 \%$ of men's.

Clearly women could not rely on class solidarity. They had to do it themselves. Which they did. Women civil servants organising in their own union during the 1930s were in the vanguard of campaigning for equal pay, and, together with teachers, post office workers and local government officers, continued the pressure through the 1950s and in the face of governments saying they could not afford to foot the equal pay bill. ${ }^{97}$ Finally in 1955 the government moved to equalise pay in the public sector by 1961 by 7 stages. Although a decisive victory for women, it was limited to a select group of skilled and professional women. Nurses, women clerical, and manual workers in the public sector were all excluded. They had to wait a further decade, during which the process of campaigning and prevarication was repeated, until the Ford women car seat sewing machinists' 1968 strike for pay parity with men. These women, doing women's work (sewing) in the car factories, became a cause celebre, although they only gained $92 \%$ of men's pay, and had to continue the fight for a further 16 years for regrading.

This ambivalence about gender pay relations can be seen to be repeated down the decades, if not the centuries. When in 1975 the TUC Congress resolved that ' $a$ woman should be paid the wage a man would be paid if he were doing the job. This will only be achieved by intensive industrial campaigns for higher wages for women', it illustrates the misunderstanding and misrepresentation of the position of women. First, it assumes that women work in the same jobs as men. Not only has occupational gender segregation been systemic, it got worse following the 5-year gap between the passing of the 1970 Equal Pay Act and its final implementation in 1975 as employers further segregated the sexes at work to head off claims for equal pay for like work. And as Coote and Campbell comment, 'those intensive campaigns did not take place'. ${ }^{98}$

Not until the Equal Opportunities Commission took the British government to the European court in the early 1980s to claim compliance with European Union

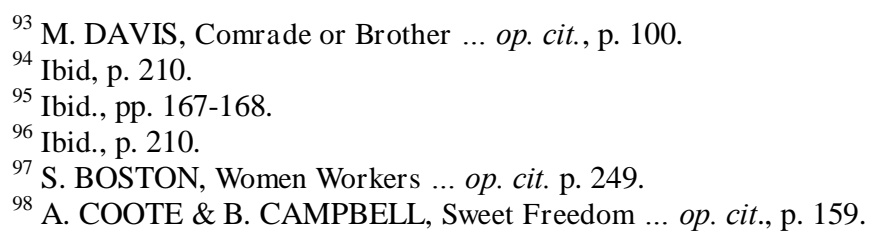


Article 119 (now Article 141) that women's pay should be of equal value to men's, did things change much. Then a series of long drawn out, but landmark cases were taken by women, supported by their unions. The first of these was shipyard cook Julie Hayward, whose mainly male union colleagues backed her successful claim for equal pay for work of equal value with male workers at Merseyside shipbuilders Cammell Laird in 1983. ${ }^{99}$

Even though solidarity between the genders recognises equalising pay as 'good sense', too often 'common sense', ${ }^{100}$ driven by men's patriarchal interests, prevails. Coote and Campbell describe how the conflict between men's and women's interests lies 'beneath the surface of the TU's fight for equality like a wrecked tanker - polluting the waters and impeding all passage'. Nobody wanted to admit it was there, ${ }^{101}$ although as with the textile workers a century earlier, there are many examples of gender solidarity, such as the Northern Ireland cleaners in the health service case where male comparators supported their sisters over six years all the way to the High Court. ${ }^{102}$

The gender pay gap is smaller in the public than the private sector, although this is due in no small part to both the feminisation of the sector and the therefore disproportionately high number of low paid part time workers. ${ }^{103}$ Nevertheless, the public services union UNISON and other public sector unions have pursued a series of notable equal pay cases which have changed the bargaining landscape. Carol Thornley, who has carried out extensive research in the field, notes that:

the formation of UNISON produced an important change in worker representation and shifted the balance of power in significant parts of the public sector. Its formation provided a link between previously divided workers, and brought into full focus the needs of a membership three-quarters of which are women and one-third of whom work parttime. Some sophisticated and multi-stranded approaches have been taken: campaigns focused around low pay have provided a solidaristic basis for action combined increasingly around 'education, negotiation, and litigation' in occupations such as health care assistants, teaching assistants, school meals workers, and cleaners.$^{104}$

\footnotetext{
${ }^{99}$ This, the Ford dispute, and other notable Equal Pay stories are told in the UK TUC's Equal Pay Archive and series of short DVDs, launched in 2008. (TUC, The Equal Pay Story scenes from a turbulent history, Recording Women's Voices, A TUC oral history project on equal pay, London: TUC, 2008). See www.tuc.org.uk/equality.

${ }^{100}$ Ardha Danieli illustrates this paradox in her discussion of ways in which equality 'good sense' measures involving a theoretically coherent intellectual and reasoned ideology become subverted through masculinised 'common sense' forms of resistance (A. DANIELI, 'Gender: the missing link in industrial relations research' in Industrial Relations Journal. Vol 37:4 July 329-344, 2006, p. 336.

${ }^{101}$ A. COOTE \& B. CAMPBELL, Sweet Freedom ... op. cit., p. 165.

${ }^{102}$ A. MILLER, Winning Equal Pay: the value of women's work. TUC History and work related learning on-line, TUC, 2008. www.unionhistory.info/equalpay.

${ }^{103} \mathrm{C}$. THORNLEY, 'Unequal and low pay in the public sector' Industrial relations Journal: Special Issue on Gender and Industrial Relations. July. Vol 37, 4, pp. 344-359, 2006350)

104 Ibid., p. 353.
} 
Nevertheless the gender pay gap in the UK hovers around $17 \%$ when comparing hourly earnings of full time workers - and is getting wider. The weekly pay gap is $21 \%$, and the gap between the average part-time woman's wage and a full-time men's wage is 41 per cent. ${ }^{105}$. Among measures being called for by the TUC is placing the role of workplace Equality Representatives on a statutory basis encouraging them to use collective bargaining to tackle pay and equality issues ${ }^{106}$. Throughout the history of women's trade unionism, the evidence is that equal pay along with other demands of women, regularly fall off union bargaining agendas when the negotiating gets tough. ${ }^{107}$ As Cynthia Cockburn has commented, 'the most important single change within unions, and the hardest to achieve.... is shifting the priorities on the unions' collective bargaining agenda to take full account of women's needs and priorities'. ${ }^{108}$ Even in 2007, only three unions in the TUC's Equality Audit employed women negotiators in proportion to the female membership, and those were small professional unions: 'It is very rare (to see women) at the level of senior official and negotiating official levels'. ${ }^{109}$

In a recent survey of paid union officers, researcher Ed Heery concluded that addressing equal pay bargaining is a function of women's voice within unions, the characteristics and preferences of bargainers themselves and of a favourable public policy environment. ${ }^{110}$ This built on earlier work that suggested that women full time officers were more likely to make a priority of 'women's' bargaining issues. ${ }^{111}$ Yet despite union demands for the government to make pay audits as mandatory on employers in its new 2009 equalities legislation, this is being watered down with the argument that it is 'a step too far' in a recession. ${ }^{112}$ At the current rate of change, it will take 140 years to close the part-time pay gap - 'we are simply not prepared to wait that long', said Katherine Rake, director of the Fawcett Society, which campaigns for women's equality. ${ }^{113}$

\section{Conclusions}

Certainly, women trade union activists in the UK are not prepared to wait that long either. Nevertheless it is difficult to draw entirely positive conclusions about their role and place in their unions today. As I have written before, is the glass half full or half empty? Are advances being made? How far does the resistance from

${ }^{105}$ National Statistics On Line 2008, TUC 2008, p. 5.

106 TUC, Closing the Gender Pay Gap, An Update report for TUC Women's Conference 2008. London: TUC, 2008, p. 29.

${ }^{107}$ T. COLLING \& L. DICKENS, Equality Bargaining, Why Not? Warwick University/EOC, 1989.

${ }^{108}$ C. COCKBURN, Women, Trade Unions and Political Parties. Fabian Research Series No 349. September. London: The Fabian Society, 1987, p. 12.

${ }^{109}$ TUC, Closing the Gender Pay Gap, op. cit., p. 30.

${ }^{110}$ E. HEERY, 'Equality Bargaining: Where, Who, Why?' Gender, Work \& Organization, Volume 13 Issue 6, 2007, p. 522.

${ }^{111}$ E. HEERY \& J. KELLY, 'Do female representatives make a difference? Women full-time officials and trade union work', Work, Employment and Society. Vol 2:4 pp. 487-505. December, 1988, p. 501.

${ }^{112}$ Amelia GENTLEMAN, 'Equal pay is a step too far in recession, says rights body', The Guardian, Monday 16 March 2009.

${ }^{113}$ Fawcett Society, 'Women Shortchanged on Equal pay', www.fawcettsociety.org.uk, 2008. 
encounters with traditional masculinised trade unionism mean two steps forward and one back ${ }^{114}$

Also, as we have seen in this article, women are also both the same and different. As gender always intersects with other diversities, women too are divided by class, sexuality, ethnicity and race, disability, age, and so on. However, since all women share a position of gender subordination in their own particular sphere, there will also always be areas of commonality where their interests meet at a particular point of time, of struggle. In discussing how to deal with this, Nira Yuval-Davis ${ }^{115}$ argues for the idea of 'transversal politics' whereby feminist politics should incorporate the notion of 'women's positionings' into their agendas. Thus women (and men) from different constituencies may remain rooted in their own membership and identity, but simultaneously be prepared to shift into a position of exchange with those from different groups and group interests in pursuit of a common agenda. ${ }^{116}$ This can be seen especially in the early days of women's unionism in Britain, where middle class, educated women were able to use their resources to support their working class sisters and help them to help themselves and develop their particular form of trade unionism. More recently women's and union initiatives of autonomous organising of diversity groups, and coalitions and networking across them are becoming increasingly important. ${ }^{117}$

Clearly the tensions between women's challenge and traditionalism's backlash, experienced by women throughout the history of women's unionisation, are likely to continue even while the imperative for union solidarity and renewal demand that unions make space for women to develop their own agendas according to their needs as well as standing shoulder to shoulder with the brothers. Accommodating both trajectories in the reshaping of traditional solidarities will continue to be uncomfortable, but nevertheless is essential.

\section{Bibliography}

BOSTON, S., Women Workers and Trade Unions. London: Lawrence \& Wishart, 1987.

BRANSON, N., 'New Introduction' to DRAKE, B. 1920. Women in Trade Unions. Joint Committee [Fabian Society Research Department, and FS Women's group]. London: Virago Press, 1984.

${ }^{114}$ S. LEDWITH \& F. COLGAN, 'Tackling Gender, Diversity and Trade Union Democracy ...', op. cit., p. 21

${ }^{115}$ Nira YUVAL-DAVIS, 'Beyond differences: women, empowerment and coalition' in $\mathrm{N}$. CHARLES, \& H. HINTJENS, Gender, Ethnicity and Political Ideologies. London: Routledge, 1998.

${ }^{116}$ S. LEDWITH, 'The Future as Female?', op. cit., p. 116

${ }^{117}$ see for example F. COLGAN, 'Recognising the lesbian and gay constituency in UK trade unions: moving forward in UNISON?' Industrial Relations Journal. 30, 5, pp. 444-63, 1999 and G. HEALY, H. BRADLEY \& N. MUKHERJEE, 'Individualism and collectivism revisited: a study of black and minority ethnic women', Industrial Relations Journal. 35:5, 2004, pp. 451-466. 
BRISKIN, L., 'Union Women and Separate Organizing', in L. BRISKIN and P. MCDERMOTT (eds), Women Challenging Unions, Toronto: University of Toronto Press, 1993, pp. 89-108.

BRISKIN, L., 'Autonomy, Diversity and Integration: Union Women's Separate Organizing in North America and Western Europe in the Context of Restructuring and Globalization',Women's Studies International Forum, 22, 4, 1999, 543-554.

COCKBURN, C., Brothers: Male Dominance and Technological Change. London: Pluto, 1983.

COCKBURN, C., Women, Trade Unions and Political Parties. Fabian Research Series No 349. September. London: The Fabian Society, 1987.

COLGAN, F., 'Recognising the lesbian and gay constituency in UK trade unions: moving forward in UNISON?’ Industrial Relations Journal. 30, 5, pp. 444-63, 1999.

COLGAN, F. \& LEDWITH, S, 'Sisters Organising - Women and their Trade Unions' in S. LEDWITH \& F. COLGAN (eds). Women in Organisations: Challenging Gender Politics. Basingstoke: Macmillan Business, 1996

COLLING, T. and DICKENS, L., Equality Bargaining, why not? Warwick University/EOC, 1989.

COOTE, A. \& CAMPBELL, B., Sweet Freedom: the struggle for women's liberation. Oxford: Blackwell, 1987 ( $2^{\text {nd }}$ edition).

DANIELI, A., 'Gender: the missing link in industrial relations research' in Industrial Relations Journal. Vol 37:4 July 329-344, 2006.

DAVIS, M., Comrade or Brother? The history of the British Labour Movement 1780-1951. London: Pluto Press, 1993.

DRAKE, B. (1920) Women in Trade Unions. London: Labour Research Department. Republished by Virago Press, 1984.

DROMEY, J. and TAYLOR, G., Grunwick, the Workers'Story. London; Lawrence and Wishart, 1978.

ELLIS, V., The Role of Trade Unions in the Promotion of Equal Opportunities. London: EOC/SSRC Joint Panel on Equal Opportunities, 1981.

Fawcett Society, 'Women Shortchanged on Equal pay', www.fawcettsociety.org.uk/index.asp?PageID=209 (2008)

FRYER, B., 'The making of UNISON: a framework to review key events, processes and issues' in M. TERRY (ed) Redefining Public Sector Unionism: UNISON and the future of trade unions. London: Routledge, 2000.

GUPTA, R., 'Heroines of the Picket'. London: The Guardian, 2005.

HEALY, G., BRADLEY, H. \& MUKHERJEE, N., 'Individualism and collectivism revisited: a study of black and minority ethnic women', Industrial Relations Journal. 35:5, 2004, pp. 451-466. 
HEERY, E. and KELLY, J., 'Do female representatives make a difference? Women full-time officials and trade union work', Work, Employment and Society. Vol 2:4 pp. 487-505. December, 1988.

HEERY, E., 'Equality Bargaining: Where, Who, Why?' Gender, Work \& Organization, Volume 13 Issue 6, 2007, pp. 522 - 542.

ILWU [1997] Women of the Waterfront bring struggle to ILWU territory. The Dispatcher interview with Women of the Waterfront: Collette Melia and Sue Mitchell The Dispatcher, International Longshore and Warehouse Union. www.labournet.docks [accessed 21/11/08]

Industrial Workers of the World www.indymedia.org.uk The Black Country Living Museum, Tipton Road, Dudley, West Midlands DY1 4SQ. www/bclm.co.uk [accessed November 12, 2008]

KIRTON, G. \& HEALY, G., 'Transforming union women: the role of women trade union officials in union renewal' Industrial Relations Journal, 30: 31-34, 1999.

KIRTON, G. \& HEALY, G., 'Shaping union and gender identities: a case study of women-only trade union courses', British Journal of Industrial Relations. 42: 2 June, 2004, pp. 303-323.

LAHIRI, S. Moving Here. Migration Histories, www.movinghere.org.uk, accessed 21/11/08.

LEDWITH, S. \& COLGAN, F., 'Tackling Gender, Diversity and Trade Union Democracy: A Worldwide Project?', in COLGAN F. \& LEDWITH S. (eds), Gender, Diversity and Trade Unions: International Perspectives, London: Routledge, 2002.

LEDWITH, S., 'The future as Female?' in C. PHELAN (ed) The Future of Organised Labour, Oxford: Peter Lang, 2006.

LEDWITH, S. 'Encounters between gender and labour politics; towards an inclusive trade union democracy', Equality Theory and Research, ed. OZBILGIN M. \& ELGAR E. (2009/forthcoming)

LEDWITH, S, HAYES, M, JOYCE, P. \& GULATI, A. 'The making of women trade union leaders', Industrial Relations Journal 21, 2, 1990, pp. 112-25

LIDDINGTON, J., 'History, feminism and gender studies', University of Leeds, 2001.

LIDDINGTON, J \& NORRIS, J, One Hand Tied Behind Us: The rise of the women's suffrage movement, Virago Press, 1978; new 21st anniversary edition, Rivers Oram Press, 2000.

McBRIDE, A., Gender Democracy in Trade Unions, Aldershot: Ashgate, 2001.

McBRIDE, A. \& Waddington, J., 'Union Mergers and Gender Democracy', Bulletin of Comparative Labour Relations, 67, Challenges of European Employment Relations, 2008.

MERCER, S. \& NOTLEY, R., Trade Union Membership 2007. A National Statistics Publication. London: Department for Business and Regulatory Reform, 2008. 
MILLER, A., Winning Equal Pay: the value of women's work. TUC History and work related learning on-line, TUC, 2008. www.unionhistory.info/equalpay

National Statistics On Line 2008, November $14^{\text {th }}$, www.statistics.gov.uk

PARKER, J., 'Women's Groups in British Unions', British Journal of Industrial Relations. 40, No. 1. 23-48, 2002.

PARKER, J., Women's Groups and Equality in British Trade Unions, Lampeter: Edwin Mellen, 2003.

ROWBOTHAM, S., Hidden from History. London: Pluto Press, 1977 ( $3^{\text {rd }}$ edition).

SERTUC, Treading Water.... SERTUC's Eighth Survey of Equality in Trade unions. London: Southern and Eastern Regional Council, 2008.

SHAW, M., \& MUNDAY, M., 'Complexities of class and gender relations: Recollections of women active in the 1984-5 miners' strike', Capital and Class, Autumn, 87: 151-174, 2005.

SIVANANDAN A., 'The Grunwick Strike', Race \& Class, Vol. 19, no. 1, summer, 1977.

THORNLEY, C., 'Unequal and low pay in the public sector' Industrial relations Journal: Special Issue on Gender and Industrial Relations. July. Vol 37, 4, pp. 344 359, 2006.

Trade Union Family Trees, Teachers' Trade Unions. Trade Union Ancestors, www.unionancestors.co.uk accessed Nov 23, 2008.

TUC, Women Workers: Report of the $48^{\text {th }}$ annual conference of representatives of trade unions catering for women workers. London: TUC, 1977.

TUC, 51 ${ }^{\text {st }}$ TUC Women's Conference: Report for 1980-81 of the TUC Women's Advisory Committee. London: TUC, 1981.

TUC, A woman's place is in a union. Report to $75^{\text {th }}$ TUC Women's Conference March. London: TUC, 2005.

TUC, TUC Equality Audit. A Statistical Report on Trade Union Action on Equality, London: TUC, 2007.

TUC, The Equal Pay Story - scenes from a turbulent history, Recording Women's Voices, A TUC oral history project on equal pay, London: TUC, 2008.

TUC, Organising for the Future: Women in trade unions, London: TUC, 2008.

TUC, Closing the Gender Pay Gap, An Update report for TUC Women's Conference 2008. London: TUC, 2008

UNISON Rules 1993, London: UNISON, 1993.

WADDINGTON, J. \& WHITSTON, C., 'Why Do People Join Unions in a Period of Membership Decline?' British Journal of Industrial Relations, Volume 35 Issue 4, pp. 515 - 546, 1997.

WADDINGTON, J. \& KERR, A., 'Membership retention in the public sector', Industrial Relations Journal, Volume 30 Issue 2, pp. 184-196, 1999a. 
WADDINGTON, J. \& KERR, A., 'Trying to stem the flow. Union membership turnover in the public sector', Industrial Relations Journal, Volume 30 Issue 3, pp. 184-196, 1999 b.

WALTERS, Sally, 'Female Part-time Workers' Attitudes to Trade Unions in Britain', British Journal of Industrial Relations. 40: 1 March 2002, pp. 49-68.

WILSON, T., The Future for Unions. London: Unions 21, 2007

YUVAL-DAVIS, N., 'Beyond differences: women, empowerment and coalition' in CHARLES, N. \& HINTJENS, H. Gender, Ethnicity and Political Ideologies. London: Routledge, 1998. 


\title{
Le TUC et l'Europe, le virage des années Thatcher : de l'internationalisme de principe au pragmatisme pro-européen
}

\author{
Anne-Marie MOTARD \\ Université Paul Valéry - Montpellier III
}

L'évolution de la position de la Confédération des syndicats britanniques (Trades Union Congress) sur la question européenne depuis 1945 est un parcours sinueux qui l'a menée de l'internationalisme de principe de l'après-guerre au prosélytisme pro-européen de l'après-Thatcher. L'une des premières organisations indépendantes de représentation des syndicats dans le monde, le Trades Union Congress (TUC), créé à Manchester en juin 1868, constitue à ses débuts une sorte de club jouant le rôle de groupe de pression auprès des instances de représentation politique afin de promouvoir les droits syndicaux et de protéger les syndicalistes des excès de certains employeurs. Après la première guerre mondiale, le TUC apparaît comme l'organe représentatif des syndicats britanniques au niveau national, avec une influence renforcée à la fois par des réformes structurelles internes et par l'échec du militantisme direct pratiqué par certains syndicats. De plus, la confédération syndicale resserre, à ce moment-là, ses liens avec les travaillistes en mettant en place des commissions mixtes de consultation et d'élaboration du programme politique du parti.

L'influence du TUC va se renforcer pendant les années 1920 et 1930, et plus encore pendant la deuxième guerre mondiale au cours de laquelle les leaders syndicaux vont être étroitement associés aux responsabilités gouvernementales. La nomination d'Ernest Bevin, secrétaire général du puissant syndicat des transporteurs (TGWU), à la tête du ministère du travail symbolise l'importance du rôle joué par le mouvement syndical pendant la guerre, notamment pour assurer la mobilisation de la main d'œuvre. Walter Citrine, secrétaire général du TUC de 1926 à 1946, souligne le renforcement de la légitimité des syndicats qui a résulté de leur participation à l'effort de guerre: "L'influence des syndicats s'est extrêmement renforcée pendant la guerre, et à aucun autre moment de l'histoire britannique la contribution des organisations de travailleurs n'a été plus facilement et largement reconnue $^{1}$ ». En 1945, la puissance des syndicats britanniques parait incontestée, et leur rôle dans la société clairement établi. Or, pendant la période qui suit, le TUC maintient une relation distanciée avec ses partenaires européens, qui oscille entre l'indifférence, la méfiance ou même l'hostilité, et un intérêt mesuré, une curiosité

\footnotetext{
1 "The influence of the trade unions has been enormously strengthened during the war and at no period in British history has the contribution which the organised workers have made to the success of their country been more widely and readily recognised". (Taylor, p. 76)
} 
teintée de perplexité. La prudence dont la confédération fait preuve vis-à-vis de tout engagement européen dans les années 1950 et 1960 se transforme en véritable rejet dans les années 1970. Mais un changement d'attitude se fait jour dans les années 1980 qui va aboutir à un véritable retournement de situation, le TUC se faisant à la fin du $\mathrm{XX}^{\mathrm{e}}$ siècle et au début du $\mathrm{XXI}^{\mathrm{e}}$ siècle le chantre de l'intégration européenne. Comment expliquer la persistance des attitudes anti-européennes au sein du TUC, et, au-delà dans les syndicats en général, pendant des décennies ? Comment le changement d'attitude à la fin des années 1980 s'est-il opéré ? A-t-il été la conséquence d'un revirement soudain ou l'aboutissement d'un long processus ? Quelle influence le TUC a-t-il sur la définition des priorités économiques et sociales du gouvernement ? Quel rôle joue-t-il dans la société britannique ? Après la crise qui a touché l'ensemble du mouvement syndical dans les années 1980 a-t-il même encore un rôle à jouer ? On peut esquisser des réponses à ces questions en analysant l'évolution du discours de la confédération sur l'idée européenne et en mettant en perspective les transformations du mouvement syndical britannique, tout à la fois soumis à l'évolution sociale, économique et politique de la Grande-Bretagne et acteur du changement.

Il apparaît en fait que l'engagement européen du TUC varie d'une manière inversement proportionnelle à la puissance nationale du mouvement syndical. La construction européenne est négligée, voire repoussée, tant que le mouvement syndical est en position de force dans la société britannique. A contrario, elle devient une ressource fortement revendiquée par un syndicalisme en crise qui se tourne vers l'Europe pour tenter de juguler sa perte d'influence.

\section{Puissance du TUC, ignorance de l'Europe}

Après la deuxième guerre mondiale, l'attitude du mouvement syndical reflète le climat politique britannique : la Grande-Bretagne sort du conflit du côté des vainqueurs et il semble qu'un sentiment de supériorité morale et d'assurance quant à son rôle de grande puissance soit partagé par l'ensemble des couches sociales. Les prises de position du TUC en matière de relations internationales s'inscrivent sans difficulté dans les trois cercles de la politique étrangère définis par Churchill en 1948 par ordre d'importance décroissante: le Commonwealth, la «relation spéciale » avec les États-Unis et, en dernier lieu, l'Europe. Ce qui domine alors est un internationalisme de principe qui paraît incompatible avec tout engagement européen.

Le TUC affirme régulièrement son attachement aux principes de solidarité entre les travailleurs du monde entier, sans privilégier aucune aire géographique. Mais le laconisme des leaders syndicaux et l'absence de véritables débats lors des congrès de l'époque témoignent d'un manque d'intérêt réel pour les questions internationales. Au-delà des déclarations de principe et de l'intervention traditionnelle de quelques confrères, l'action internationale du TUC reste discrète. De fait, les actions concrètes entreprises occupent une place restreinte dans les rapports du General Council, exécutif du TUC : guère plus d'une page ou deux, relatant essentiellement des rencontres avec des représentants de syndicats étrangers ou des visites outre-mer. 